\title{
2-D SIMULATION OF OVERLAND FLOW AROUND GULLY HEADCUT
}

\author{
Ashis Kumar DEY 1 , Tadanori KITAMURA ${ }^{2}$ and Tetsuro TSUJIMOTO 3 \\ ${ }^{1}$ Student Member of JSCE, Postgraduate Student, Dept. of Civil Engineering, Nagoya University \\ (Furo-cho, Chikusa-ku, Nagoya 464-8603, Japan) \\ ${ }^{2}$ Member of JSCE, Dr. of Eng., Research Associate, Dept. of Geo- \& Environmental Engineering, Nagoya University \\ ${ }^{3}$ Member of JSCE, Dr. of Eng., Professor, Dept. of Geo- \& Environmental Engineering, Nagoya University
}

\begin{abstract}
Formation and migration of gully headcut is one of the complicated phenomena, which often appears in incised channels. Flume experiments have been conducted to investigate the flow field along and around the headcut. The fixed bed experiments with oblique headcuts show that the flow is concentrated to the head (upstream part) of the gully, which has been reproduced in numerical simulations for both of fixed and movable bed conditions. Headcut migration rate depends on the unit discharge along the brink and the change in elevation of energy-grade line passing the headcut. The initial shape of the headcut is an important parameter for the formation and movement of gully headcut. A sharp shape at the head of the headcut is required for the proper development of gully.
\end{abstract}

Key Words : overland flow, gully, headcut migration, depth-averaged flow simulation, oblique step, brink

\section{INTRODUCTION}

Gully erosion is the process in which the flow is concentrated in a narrow channel and removes soil to bring spatial variety of depth within short period. The erosion process gradually migrates upstream with time. Headcut is a sudden change in bed elevation or a knickpoint at the leading edge (head) of a gully. Headcuts can range from few centimeters to several meters in height, depending on several factors. Gully erosion is usually accompanied with headcuts. A gully headcut is one of important fluvial processes not only on slopes but also in rivers. For example, Gay et al. (1998) observed that overland flow causes cut off in meandering channels with gully headcuts. Fig.1 shows the typical overland flow pattern with gully erosion.

Formation and movement of a gully headcut is a complex phenomenon. The headcut migration is controlled by the hydraulic characteristics of flow and by the erosion resistant properties of earth material at the flow boundary. Headcuts migrate when a geomorphic threshold is violated due to either a decrease in the resistance force of earth materials or an increase in the attack force of flow or both.

There are several experimental studies on a gully headcut (Bennett et al., 1997; Hanson et al., 1997; Stein et al., 1997; Robinson, 1996; Temple, 1992; and so on). Numerical simulation models on the headcut migration in vertical 2-D framework were also investigated (Jia et al., 1999; Kitamura et al., 1999).

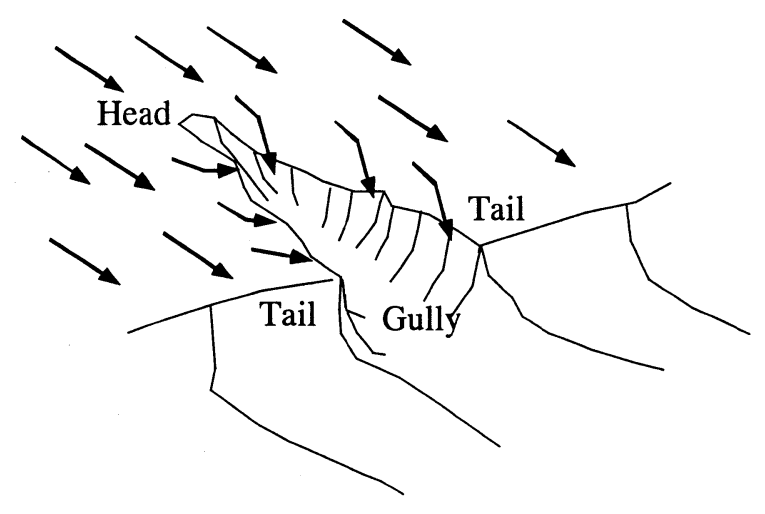

Fig.1 Overland flow and gully erosion

On the other hand, the number of both experimental and analytical studies on the heterogeneous gully headcut is relatively small. Izumi (1993) conducted an analytical study on the development of a gully headcut. He employed a 
linear stability analysis on the development of the small disturbance along laterally uniform headcut. His analysis clarified that when there is small disturbance along headcut, the unit discharge through the brink is also disturbed, which makes the erosion rate change, and then the gully develops. However, his analysis could not explain which wave number is dominant for the development of gully.

In the present study, we solve the non-linear equations to govern the flow field around headcut, and then investigate the development of the gully headcut by using the flow simulation model. Firstly, flume experiments are conducted to observe the flow field around the gully headcut and to get the experimental data. Secondly, the flow simulation model is verified by using the experimental data. Finally, the gully headcut development is simulated with empirical relationship among headcut migration rate, unit discharge through the brink, and the vertical-drop of energy line passing the headcut.

\section{EXPERIMENTAL INVESTIGATION}

\section{(1) Set-Up and Procedure}

The experiments for the verification of the flow simulation through headcut were conducted in a flume of $20 \mathrm{~m}$ long and $0.50 \mathrm{~m}$ wide. The glass-made side-walls of the flume provided us an opportunity to observe the flow pattern along the headcut. Flow discharge was controlled by an adjustable inlet valve and monitored through a digital display-meter. Water was initially discharged into an inlet tank, which acted as a reservoir for damping the turbulence in the test section. The flume bed in the test section was made of wood in which a $0.10 \mathrm{~m}$ vertical-drop was located at the end of it. A movable point-gauge was used to measure the water surface and bed elevation. The velocities along the flow direction at different locations were measured by a miniature propeller current-meter, which was connected with a digital data recorder. To get the accurate and stable value, the average velocity of a $30 \mathrm{sec}$ time-span was taken. The bed slope was fixed as 1:1000 for all experiments. Fig.2 shows the schematic diagram of the experimental set-up.

\section{(2) Results and Discussions}

In experiments, three different cases were conducted by changing the discharge and headcut pattern. Table-1 summarizes all of the experimental conditions. Within the total test section, our zone of interest was only a length of $4 \mathrm{~m}$ upstream from the point B' of Fig.2. The water depth at upstream of AA' line could be regarded as the normal depth of the flow. So, we set the point $A$ as the origin of all measurements.

\section{a) Water depth along $x$-direction}

Fig.3 shows change of the water depth $(h)$ along $x$-direction for different transverse location. It is observed that water depth gradually decreases with $x$-distance but suddenly decreases immediately behind the brink. Near the brink, for the same $x$ location $h$ gradually increases with the $y$-distance. The phenomena observed in all cases clearly indicate that the flow is concentrated around point $\mathrm{B}$, the head of the headcut BB'.

\section{b) Water depth and unit discharge along headcut}

Fig.4 shows that the higher water depth and larger unit discharge (discharge through unit width, q) are observed at the point B and decrease gradually with distance along the headcut. There is significant variation in both of $h$ and $q$ for Case-1 and Case-2, but a little variation for Case-3. This indicates that the value of XL (see Fig.2) has a significant effect on $h$ and $q$ along headcut.

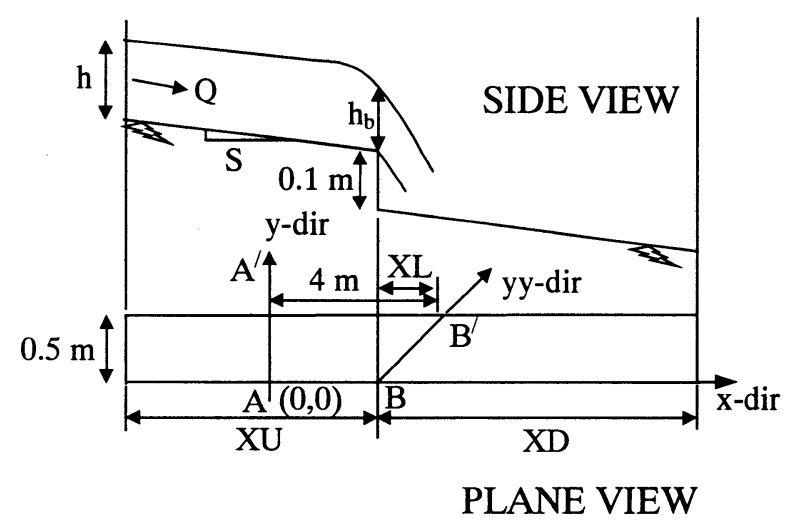

Fig.2 Schematic diagram

Table-1 Experimental conditions

\begin{tabular}{|l|l|l|l|}
\hline \multirow{2}{*}{ parameters } & \multicolumn{3}{|l|}{ experimental runs } \\
\cline { 2 - 4 } & Case-1 & Case-2 & Case-3 \\
\hline discharge, $\mathrm{Q}\left(\mathrm{m}^{3} / \mathrm{s}\right)$ & 0.010 & 0.015 & 0.010 \\
\hline $\mathrm{XU}(\mathrm{m})$ & 8.0 & 8.0 & 8.5 \\
\hline $\mathrm{XD}(\mathrm{m})$ & 12.0 & 12.0 & 11.5 \\
\hline $\mathrm{XL}(\mathrm{m})$ & 1.0 & 1.0 & 0.5 \\
\hline vertical-drop $(\mathrm{m})$ & 0.10 & 0.10 & 0.10 \\
\hline bed slope, S & 0.001 & 0.001 & 0.001 \\
\hline roughness & smooth & smooth & smooth \\
\hline
\end{tabular}



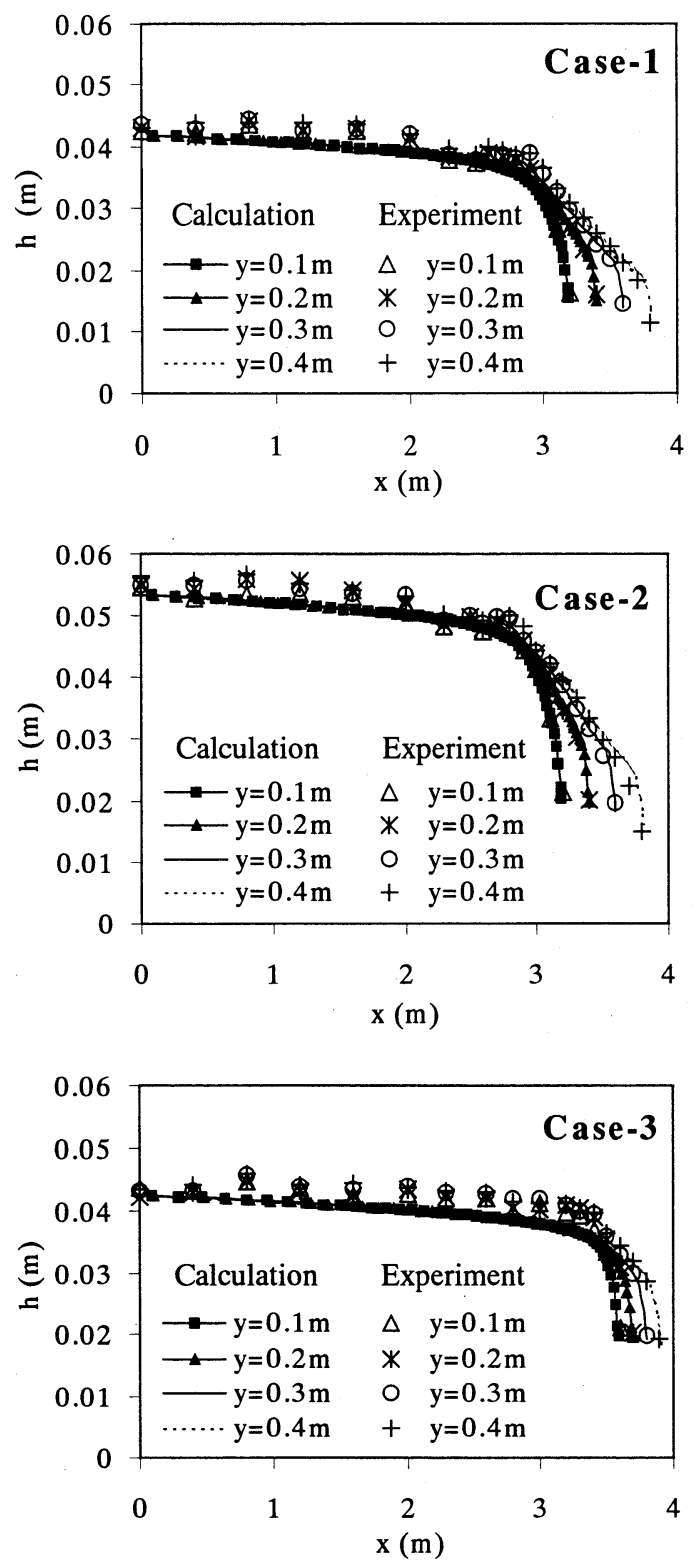

Fig.3 Water depth along $\mathrm{x}$-direction for different transverse location

\section{A MODEL FOR SIMULATING OVERLAND FLOW AROUND GULLY}

It is necessary to use a 2-D depth-averaged flow model to capture the characteristics of the discharge distribution around a gully headcut because the flow change in a plane is a key factor of this phenomenon, as we have seen in the experiment. Along the headcut line, almost critical condition of the flow appears. The variation of the water depth along the headcut controls the discharge distribution. It would be enough to simulate only the portion upstream of the headcut for investigation of the discharge distribution along the headcut. On the
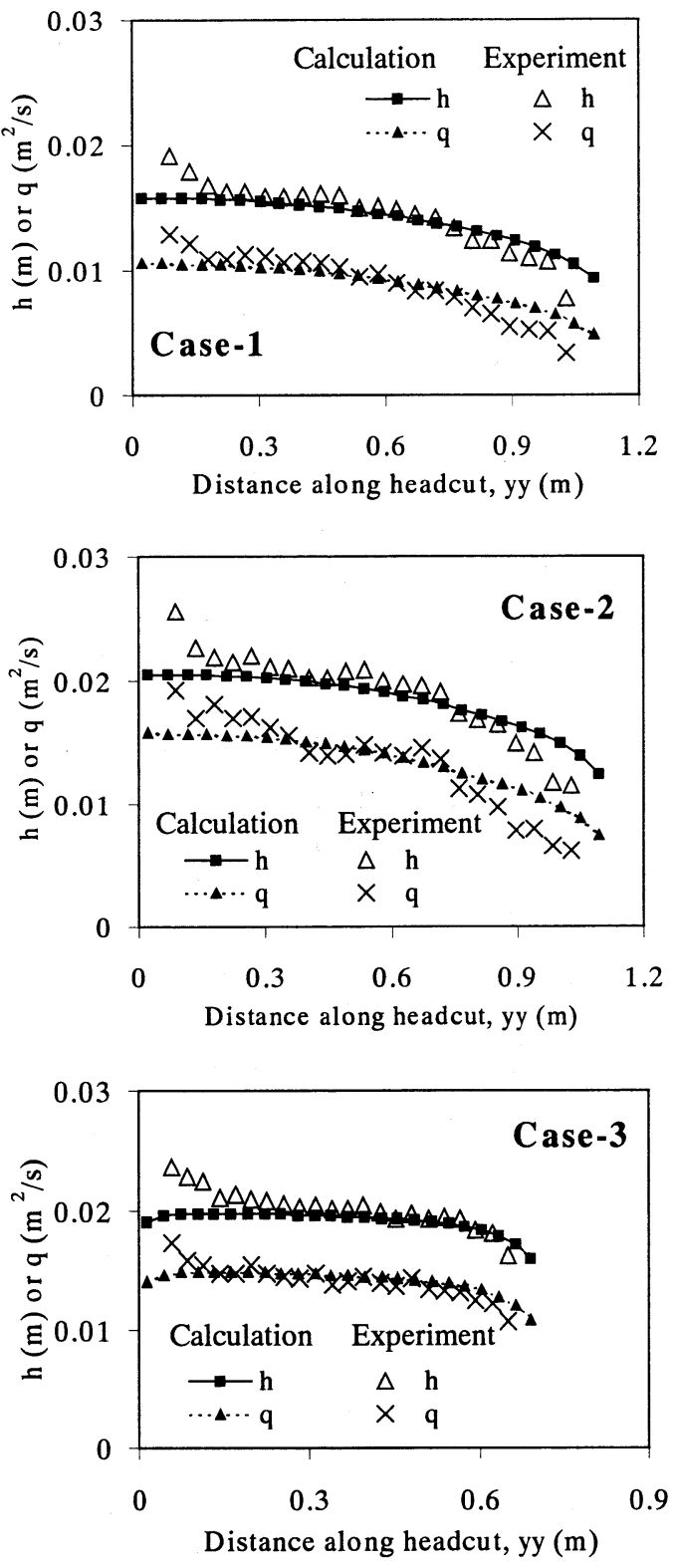

Fig.4 Water depth and unit discharge along headcut

other hand, the headcut shape in a plane is not usually so simple. It is difficult to express natural plane geometry of the headcut accurately with rectangular grid system. In the present study, a nonorthogonal boundary fitted grid system is employed to express a general shape of the headcut.

\section{(1) Governing equations}

The governing equations for a depth-averaged 2$D$ flow model can be written as follows:

$$
\operatorname{div}(\phi h \mathbf{V}-h \Gamma \operatorname{grad} \phi)=S_{\phi}
$$

Continuity equation:

$$
\phi=1 ; \quad \Gamma=0 ; \quad S_{\phi}=0
$$


$u$-equation:

$$
\begin{gathered}
\phi=u \quad ; \quad \Gamma=0 ; \\
S_{\phi}=-g h \frac{\partial \zeta}{\partial x}-C_{f} u \sqrt{u^{2}+v^{2}}+\frac{\partial}{\partial x}\left(h \tau_{x x}\right)+\frac{\partial}{\partial y}\left(h \tau_{x y}\right)
\end{gathered}
$$

$v$-equation:

$$
\begin{gathered}
\phi=v \quad ; \quad \Gamma=0 ; \\
S_{\phi}=-g h \frac{\partial \zeta}{\partial y}-C_{f} v \sqrt{u^{2}+v^{2}}+\frac{\partial}{\partial x}\left(h \tau_{y x}\right)+\frac{\partial}{\partial y}\left(h \tau_{y y}\right)
\end{gathered}
$$

where $\phi=$ transported physical quantity; $h=$ water depth; $\mathbf{V}=$ depth-averaged velocity vector; $\Gamma=$ diffusion coefficient; $S_{\phi}=$ source term; $x, y=$ Cartesian coordinates; $u, v=x$-, $y$-direction components of depth-averaged velocity, respectively; $g=$ gravitational acceleration; $\xi=$ water surface elevation; $C_{\mathrm{f}}=$ coefficient for bed-shear stress; and $\tau=$ turbulent stress in plane, which is assumed to follow the Boussinesq approximation with eddy viscosity in the present study. The following 0 -equation turbulence model is used to express the eddy viscosity:

$$
v_{T}=\alpha u * h
$$

where $\alpha=$ empirical constant; and $u_{*}=$ shear velocity. In the present study, $\alpha=0.10$ is used for all cases. In general, turbulence stresses are treated in a diffusion term. However, it is more stable for conducting the numerical simulation with the collocate grid to make the diffusion term zero virtually and to take into account the stress term in the source term (Ferziger and Peric, 1996). The turbulence stress is thereby taken into account in the source term instead of the diffusion term in the present study.

\section{(2) Numerical method to solve the governing equations}

The governing equations are discretized with volume integration in each cell with the collocate grid. The linear interpolation with the gradient of the physical quantities at the cell center is basically employed to interpolate the cell face values. However, in order to discretize the convection term the following technique is used. The cell face values are basically obtained with the upwind scheme, and then the correction term to reduce the numerical diffusion is taken into account in the source term as shown in Eq.(6) and in Fig. 5.

$$
\phi_{e}= \begin{cases}\phi_{P}+(\operatorname{grad} \phi)_{P} \cdot \mathbf{e}_{P} & \left(\mathbf{n} \cdot \mathbf{V}_{e}>0\right) \\ \phi_{E}+(\operatorname{grad} \phi)_{E} \cdot \mathbf{e}_{E} & \left(\mathbf{n} \cdot \mathbf{V}_{e}<0\right)\end{cases}
$$

where $\mathbf{e}=$ vector from the cell center to the cell face; $\mathbf{n}=$ unit normal vector to the cell face; and the subscript $e$ represents the cell face value, the subscripts $P$ and $E$ represent the cell center values.

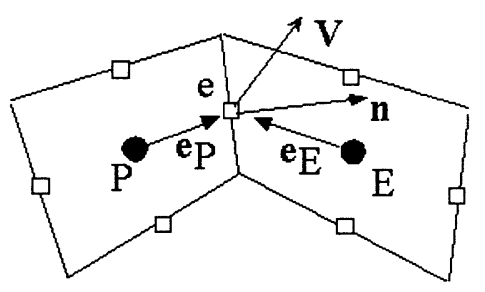

Fig.5 Modified upwind scheme

The SIMPLE method (Patanker, 1980) is employed for the water surface-velocity coupling. The interpolation technique by Rhie and Chow (1983) is adopted to prevent the numerical oscillation.

\section{(3) Boundary conditions}

Log-law is employed at the nearest node from the side-walls. The total discharge is given at the inlet boundary. Along the headcut line, the flow is almost in critical condition. However, the location at which the critical depth appears is slightly upstream from the exact brink point. According to Carstens and Carter (1955), the ratio between the depth at the exact brink, $h_{\mathrm{b}}$, and the critical depth, $h_{\mathrm{c}}$, varies from 0.69 to 0.76 as a weak function of bed-slope. In the present study, $h_{\mathrm{b}} / h_{\mathrm{c}}=0.70$ is used for giving the boundary condition of the water depth along headcut. The critical depth is determined with unit discharge perpendicular to the boundary along the headcut. Because the unit discharge is a calculated value when the water depth along headcut is given, the iteration procedure with relaxation is needed.

\section{(4) Verification of the model}

The model to simulate the flow around headcut is verified by using the experimental data of the present study. The simulated water depths and unit discharges are shown in Figs. 3 and 4 with the experimental results. The simulated results reasonably agree with the experimental data. The model can describe the characteristics of the discharge distribution in the upstream portion of the gully.

\section{SIMULATION OF DEVELOPMENT OF GULLY}

According to the previous experimental study on the headcut migration, the migration speed depends on the unit discharge. Thereby, the heterogeneity of the unit discharge along headcut would promote the gully advancement.

Temple (1992) showed the following relationship between headcut migration speed and unit discharge: 


$$
c=A q^{m} H^{n}
$$

where $c=$ headcut migration speed; $q=$ unit discharge; $H=$ elevation change in energy grade line through the headcut; $A=$ =mpirical constant which relates to soil property; and $m, n=$ empirical constants which are nearly equal to $1 / 3$ and $1 / 2$, respectively.

Combining the flow model around headcut with Eq.(7), we can simulate the change of the headcut shape. It is assumed that the headcut migration occurs in the direction perpendicular to the headcut face in the present study, which was also assumed in the linear analysis by Izumi (1993).

The effect of three different shapes of the initial gully on their developments (Fig.6) is investigated here. For these cases, the longitudinal distance between gully head and tail, $X L$, are same, but the shapes are different for each case. In the present simulation, the hydraulic conditions are the same as Case- 1 of the experiment. $H$ is assumed to be equal to the vertical-drop of bed elevation through headcut. $A=0.003, m=1 / 3, n=1 / 2$ are used.

The laterally averaged migration distances, $x x$, by the simulation are shown in Fig.7. The changes of the longitudinal distance between gully head and tail with time are shown in Fig.8. In Case-4 and Case-5, it increases with time, but decreases in Case-6. The change of the gully shape strongly depends on the initial shape of the gully. The time variations of the gully shape are shown in Fig.9. In Case-5, the shape changes very rapidly and it looks like an actual gully we observe in fields.

The above results show that the sharp angle of headcut toward upstream (convex shape) is required for gully to develop. The results of the linear analysis by Izumi (1993) showed that the any small disturbance around headcut can grow gully. However, our results with non-linear simulation clarified that if the disturbance has a mild shape toward upstream (concave shape), it cannot grow.

\section{CONCLUSION}

Flow simulation along and around headcut has been performed through flume experiments. It is proved that the flow is mostly concentrated toward the head of the headcut. The variation of water depth $(h)$ and unit discharge $(q)$ along the brink highly depends on the projected length of headcut in $\mathrm{x}$-direction $(X L)$. Higher value of $X L$ brings the larger variation of $h$ and $q$ along the brink.

2-D numerical simulation with movable bed shows quite interesting findings, although we need some experimental investigations for its proper verification. The initial shape of headcut is very important in gully development. Headcut with convex shape develops gully faster than headcut

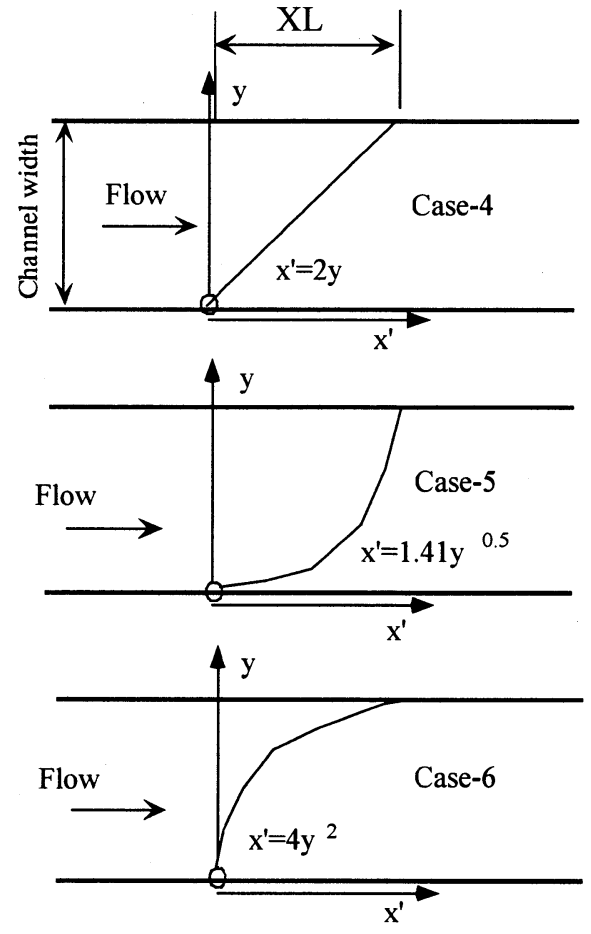

Fig.6 Initial shape of gully

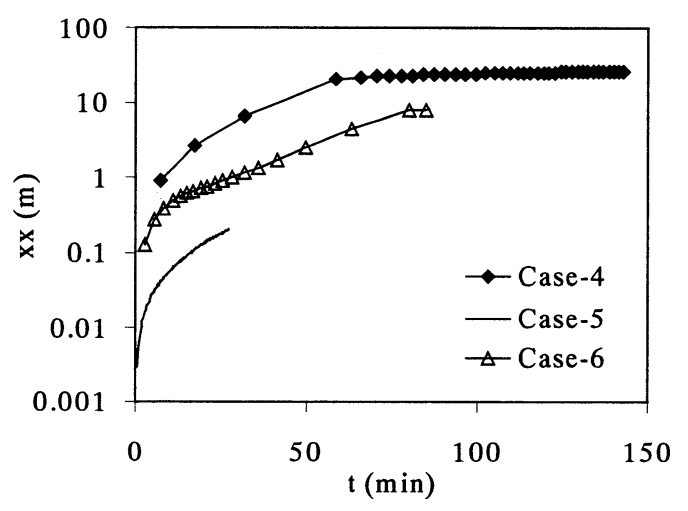

Fig.7 Laterally averaged migration distance

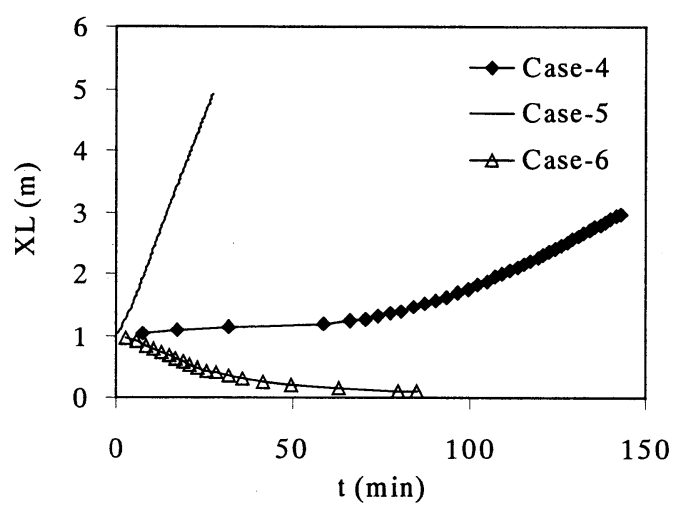

Fig.8 Time variation of longitudinal distance between gully head and tail 

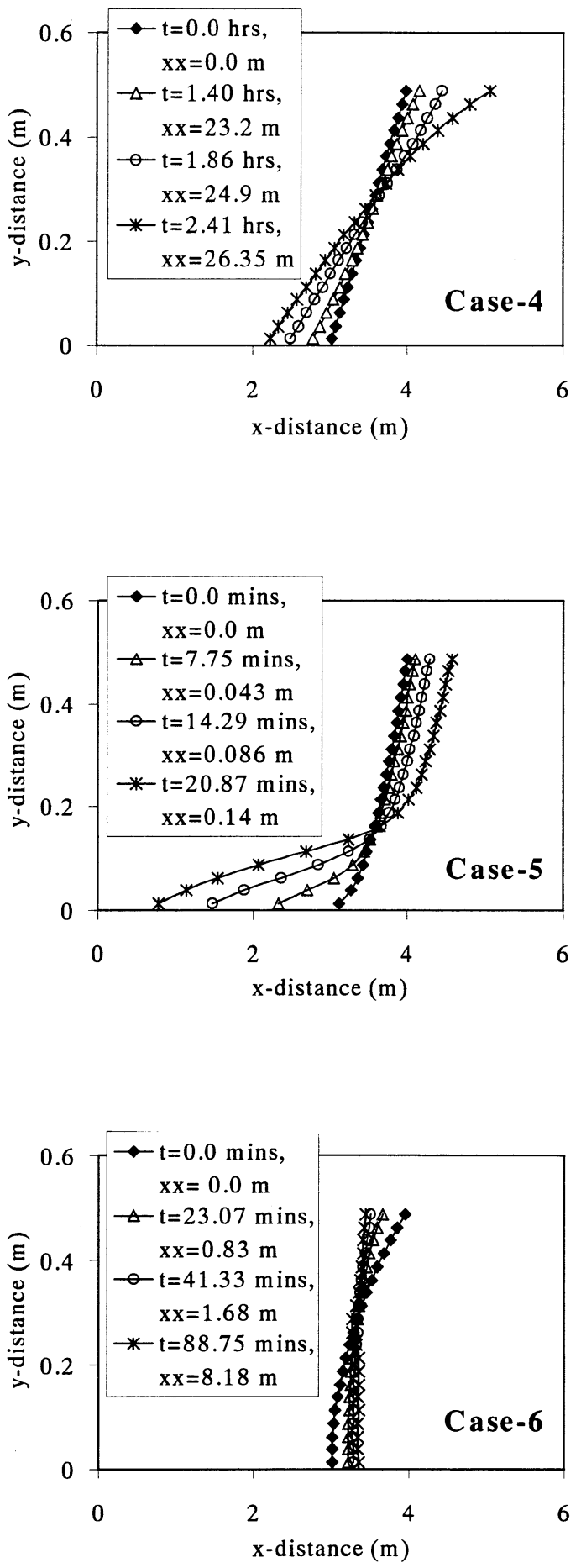

Fig.9 Changes in gully shape with time

with straight face shape. Concave initial headcut is disadvantageous factor for gully development. So, all types of lateral disturbances along headcut are not able to develop gully; sharp angle at head of the headcut is required for proper gully formation.

\section{REFERENCES}

1) Bennett, S. J., Alonso, C. V., Prasad, S. N. and Romkens, M.J.M. : Dynamics of head-cuts in upland concentrated flows, Proceedings of the Conference on Management of Landscapes Disturbed by Channel Incision, editted by S.S.Y.Wang, E.J. Lamgemdoen and F.D. Shields, Jr., pp. 510-515, 1997

2) Carsten, M. R. and Carter, R. W. : Discussion of "Hydraulics of the free overfall" by A. Fathy and M.S. Amin, Proc. ASCE, No.719, 1955.

3) Ferziger, J. H. and Peric, M. : Computational methods for fluid dynamics, Springer-Verlag, Berlin Heidelberg, 1996.

4) Gay, G. R., Gay, H. H., Gay, W. H., Martinson, H. A., Meada, R. H. and Moody, J. A. : Evolution of cutoffs across meander necks in powder river, Montana, USA, Earth Surface Processes and Landforms, 23, pp.651-662.

5) Hanson, G. J., Robinson, K. M. and Cook, K. R. : Experimental flume study of headcut migration, Proceedings of the Conference on Management of Landscapes Disturbed by Channel Incision, editted by S.S.Y.Wang, E.J. Lamgemdoen and F.D. Shields, Jr., pp. 503-509, 1997

6) Izumi, N. : Channelization and drainage basin formatioin in cohesive soils, Ph.D thesis, The University of Minnesota, 1993.

7) Jia, Y., Kitamura, T. and Wang, S.S.Y. : A model for simulating scour processes in a plunging pool of loose bedmaterial, submitted to journal of Hydraulic Engineering, ASCE, 1999.

8) Kitamura, T., Jia, Y., Wang, S.S. Y. and Tsujimoto, T. : A model for bed-scour induced head-cut, Annual Journal of Hydraulic Engineering, JSCE, pp.611-616, 1999 (in Japanese).

9) Patanker, S. V. : Numerical heat transfer and fluid flow, McGraw-Hill, New York, 1980.

10)Rhie, C. M. and Chow, W. L. : A numerical study of the turbulent flow past an isolated airfoil with trailing edge separation, ALAA J., 21, pp.1525-1532, 1983.

11)Robinson, K. M. : Gully erosion and headcut advance, Ph.D thesis, Oklahoma State University, 1996.

12)Stein, O. R., Julien, P. Y. and Alonso, C. V. : Headward advancement of incised channels, Proceedings of the Conference on Management of Landscapes Disturbed by Channel Incision, editted by S.S.Y.Wang, E.J. Lamgemdoen and F.D. Shields, Jr., pp. 497-502, 1997

13)Temple, D. M. : Estimating flood damage to vegetated deep soil spillways, Applied Engineering in Agriculture, 8(2), pp.237-242, 1992. 